\title{
AOD trends during 2001-2010 from observations and model simulations
}

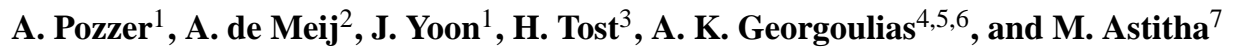 \\ ${ }^{1}$ Atmospheric Chemistry Department, Max Planck Institute for Chemistry, Mainz, Germany \\ ${ }^{2}$ Sustainable Development, NOVELTIS, rue du Lac, 31670 Labège, France \\ ${ }^{3}$ Institute for Physics of the Atmosphere, Johannes Gutenberg University Mainz, Germany \\ ${ }^{4}$ Department of Meteorology and Climatology, School of Geology, Aristotle University of Thessaloniki, Greece \\ ${ }^{5}$ Multiphase Chemistry Department, Max Planck Institute for Chemistry, Mainz, Germany \\ ${ }^{6}$ Energy, Environment and Water Research Center, The Cyprus Institute, Nicosia, Cyprus \\ ${ }^{7}$ The Department of Civil and Environmental Engineering, University of Connecticut, Storrs, Connecticut, USA
}

Correspondence to: A. Pozzer (andrea.pozzer@mpic.de)

Received: 1 September 2014 - Published in Atmos. Chem. Phys. Discuss.: 23 October 2014

Revised: 2 April 2015 - Accepted: 20 April 2015 - Published: 21 May 2015

\begin{abstract}
The aerosol optical depth (AOD) trend between 2001 and 2010 is estimated globally and regionally from observations and results from simulations with the EMAC (ECHAM5/MESSy Atmospheric Chemistry) model. Although interannual variability is applied only to anthropogenic and biomass-burning emissions, the model is able to quantitatively reproduce the AOD trends as observed by the MODIS (Moderate Resolution Imaging Spectroradiometer) satellite sensor, while some discrepancies are found when compared to MISR (Multi-angle Imaging SpectroRadiometer) and SeaWIFS (Sea-viewing Wide Field-of-view Sensor) observations. Thanks to an additional simulation without any change in emissions, it is shown that decreasing AOD trends over the US and Europe are due to the decrease in the emissions, while over the Sahara Desert and the Middle East region, the meteorological changes play a major role. Over Southeast Asia, both meteorology and emissions changes are equally important in defining AOD trends. Additionally, decomposing the regional AOD trends into individual aerosol components reveals that the soluble components are the most dominant contributors to the total AOD, as their influence on the total AOD is enhanced by the aerosol water content.
\end{abstract}

\section{Introduction}

The atmosphere is a mixture of various gases and aerosols. The increase of greenhouse gases causing climate change is partially countered or enhanced by aerosol radiation modifications (the aerosol direct effect; Andreae et al., 2005). Additionally, aerosols can modify cloud properties (indirect effects; Ramanathan et al., 2001a, b; Kaufman et al., 2002). Furthermore, depending on their composition, aerosols affect ecosystems, quality of life (cardiovascular and respiratory diseases; Lelieveld et al., 2013) and visibility. Since the late 1980s, the decline in solar radiation at the Earth's surface due to aerosol pollution (dimming) has reversed over the Northern Hemisphere (Wild et al., 2005; Wild, 2010). This change from dimming to brightening has important consequences for climate change, affecting the hydrological cycle, cloud formation processes and surface temperatures, possibly intensifying the warming trend caused by carbon dioxide $\left(\mathrm{CO}_{2}\right)$ and other greenhouse gases. Remote sensing instruments and atmospheric chemistry transport models (ACTMs) provide possibilities for improved qualitative and quantitative analysis of the global burden of atmospheric trace gases and aerosol particles. ACTMs and chemistry climate models (CCMs) are additionally used to assess the effects of future changes in aerosol (+ precursor) emissions on climate by making use of physical and chemical process descriptions in dependency of emission inventories. These emission inventories are constructed from estimates for population and 
economic growth to determine present gas phase and aerosol emissions as well as future emission scenarios. The emission inventories include natural and anthropogenic emissions relevant for aerosol formation, such as sulphur dioxide $\left(\mathrm{SO}_{2}\right)$, nitrogen oxides $\left(\mathrm{NO}_{x}\right)$, black (BC) and organic (OC) carbon, ammonia $\left(\mathrm{NH}_{3}\right)$ and many more compounds.

$\mathrm{SO}_{2}$ and $\mathrm{BC}$ are mainly emitted from fossil fuel (coal and petroleum) combustion. Primary sources for $\mathrm{NO}_{x}$ are road transport and fossil fuel combustion for energy production, and $\mathrm{NH}_{3}$ is mainly emitted from agricultural activities (waste burning and fertilizers) and to a small extent by the combustion of biofuels for energy use. The amount of $\mathrm{NH}_{3}$ emitted by agricultural activities is related to the type of fertilizer, meteorological conditions (wet/dry) and soil properties.

Since 1990 in Europe and in North America, the emissions of aerosol precursors have dropped in response to the implementation of air quality legislation (Clean Air Act Amendments), which aims to reduce the emissions of sulfur dioxide $\left(\mathrm{SO}_{2}\right)$ and nitrogen oxides $\left(\mathrm{NO}_{x}\right)$. Despite the implementation of the 11th Five-Year Plan (2006-2010) of the State Environment Protection Administration (SEPA) in China, which requires power plants to implement new air pollution reduction technologies after 2006, air pollution remains a major concern in this region (Cao et al., 2009). Half of China's $\mathrm{SO}_{2}$ emissions are attributed to the burning of coal, mostly by power plants, which are to a large degree located in the eastern part of the country where the large cities are situated. Between 2001 and 2005, $\mathrm{SO}_{2}$ emissions still increased by $27 \%$ (11th Five-Year Plan, SEPA, March 2006). Lu et al. (2010) found an increase in $\mathrm{SO}_{2}$ of $53 \%$ between 2000 and 2006 (with annual growth rate of $7.3 \%$ ), with $85 \%$ in the north and $28 \%$ in the south of the country. The increase has been reduced after 2006, due to the implementation of new emission reduction technologies (i.e., desulfurization) in power plants. $\mathrm{SO}_{2}$ emissions in China do not show a strong seasonal cycle (Zhang et al., 2009), because of the continual energy production for industry and domestic usage.

Previous studies by Ohmura (2009), Long et al. (2009), and Norris and Wild (2009) have investigated the global and regional solar radiation budget by using observations of the Global Energy Balance Archive (GEBA). Other studies have used various satellite products to investigate the impact of air pollution on the incoming solar radiation at the Earth's surface (dimming and brightening phenomena), such as the studies of Wild et al. (2005), Wild (2010, special issue J. Geophys. Res., and references therein), Pinker et al. (2005), Hinkelman et al. (2009), Mishchenko and Geogdzhayev (2007), Remer et al. (2008), Chylek et al. (2007), Lu et al. (2010), Zhang and Reid (2010), and Kishcha et al. (2009). These studies have shown elevated aerosol optical depths (AODs) (decreasing incoming solar radiation at the Earth's surface) over India, East Asia, the Bay of Bengal, and the Arabian Sea and reduced AODs (increasing incoming solar radiation) over North America and Europe.
A recent work of Hsu et al. (2012) with the SeaWIFS(Seaviewing Wide Field-of-view Sensor) instrument has shown high precision in trend derivation while reporting decreasing trends over the eastern US and Europe and increasing trends over China and India. Hsu et al. (2012) additionally have investigated the impacts of other uncertainty factors in trend estimates, e.g., retrieval algorithm deficiency and sampling bias, by comparing their results with AERONET (AErosol RObotic NETwork) and MODIS (Moderate Resolution Imaging Spectroradiometer)-Terra products. In particular the correlation analysis between large-scale meteorological events (such as the El Niño Southern Oscillation and the North Atlantic Oscillation) and SeaWiFS-retrieved AOD indicated strong influences of the climatic indices on Saharan dust outflow and biomass-burning activity in the tropics.

In de Meij et al. (2012a) the trends in AODs by remote sensing instruments have been investigated and linked to the changes of the aerosol (precursors) emissions in different emission inventories. They have found significant decreasing trends in observed AODs by MODIS, MISR (Multi-angle Imaging SpectroRadiometer) and AERONET over western Europe and the northeastern United States between 2000 and 2009 , associated with the reported negative trends in $\mathrm{SO}_{2}$, $\mathrm{NH}_{3}$ and $\mathrm{NO}_{x}$ emissions. Positive AOD trends have been found over parts of Asia. Seasonal trends were also investigated in the same study. However, no model simulations have been performed to quantify the changes in the aerosol (precursors) emissions on aerosol and AOD trends. In the present study we relate the chemical reactions of the gas and aerosol species on the trends in the simulated AODs and compare them with observations. A recent study by Chin et al. (2014) assessed the aerosol variations and trends over a period of 30 years. They used the GOCART model on $2.5^{\circ} \times 2^{\circ}$ horizontal resolution, with ACCMIP (Atmospheric Chemistry and Climate Model Intercomparison Project) and RCP8.5 emissions. Two simulations were performed, one with all natural and anthropogenic emissions and the second one with no anthropogenic emissions. They have found that changes in calculated AODs are consistent with the changes in the emissions. They also have reported that for global averaged AOD values no significant trend could be identified and that analysis on regional scale is required. However, one must be careful in the conclusions as the annihilation method (i.e., removing all the anthropogenic emissions, in this case) could lead to strong effects due to the non-linearities (e.g., chemistry, aerosol microphysics) inherent in the climate system.

The objective of this work is to investigate the causes of AOD trends over different regions of the world, especially linking the trends to changes of natural/anthropogenic emissions or changes in atmospheric dynamics. To achieve this objective, two different simulations were performed: (a) anthropogenic and biomass-burning emissions change realistically during the decade 2001-2010, and (b) anthropogenic and biomass-burning emissions are kept constant and are 
equivalent to the year 2000 (i.e., with no inter-annual emission variability).

To our knowledge, no work has been reported comparing the AOD trends from satellite measurements with model simulation with and without changing emissions for the decade 2001-2010 on global scale. This work clearly defines the causes of significant AOD trends for some regions.

In the next section, the model used in this study is presented (Sect. 3), followed by the description of the analyzed observational data set. In Sect. 4 the model results are compared with observations to evaluate its capability to reproduce AOD and AOD trends. The AOD trends in global and regional scale are analyzed in Sect. 5, and the causes of AOD trends for specific regions are discussed in details in Sect. 6 . The conclusions are summarized in Sect. 7 .

\section{Model description and setup}

The ECHAM/MESSy Atmospheric Chemistry (EMAC) model is a numerical chemistry and climate simulation system that includes submodels describing tropospheric and middle atmosphere processes and their interaction with oceans, land, and human influences (Jöckel et al., 2010). It uses the second version of the Modular Earth Submodel System (MESSy2) to link multi-institutional computer codes. The core atmospheric model is the 5th generation European Centre Hamburg general circulation model (ECHAM5, Roeckner et al., 2006). For the present study we use ECHAM5 version 5.3.02 and MESSy version 2.42.

The EMAC model has been extensively evaluated for gas tracers (e.g., Pozzer et al., 2007) and for aerosols (e.g., Pringle et al., 2010a; Pozzer et al., 2012; Astitha et al., 2012).

The modeled AOD is calculated at $550 \mathrm{~nm}$ using concentrations of dust and sea salt particles, biomass-burning products (black carbon and organic carbon) and anthropogenic aerosols (sulphates, nitrates, etc). The aerosol optical properties are calculated with the EMAC submodel AEROPT, which is based on the scheme by Lauer et al. (2007) and makes use of predefined lognormal modes (i.e., the mode width $\sigma$ and the mode mean radius have to be taken into account). Lookup tables with the extinction coefficient, the single scattering albedo and the asymmetry factor for the shortwave and extinction coefficient for the longwave part of the spectrum are pre-calculated with explicit radiative transfer calculations (see Pozzer et al., 2012). The considered compounds are organic carbon, black carbon, dust, sea salt, water-soluble compounds (WASO, i.e., all other water soluble inorganic ions, e.g., $\mathrm{NH}_{4}^{+}, \mathrm{SO}_{4}^{2-}, \mathrm{HSO}_{4}^{-}, \mathrm{NO}_{3}^{-}$) and aerosol water $\left(\mathrm{H}_{2} \mathrm{O}\right)$.

Aerosol water is determined by the aerosol partitioning model ISORROPIA II (Fountoukis and Nenes, 2007), which is based on a The Zdanovskii-Stokes-Robinson relationship (ZSR) relation (Stokes and Robinson, 1966) of the simulated aerosol compounds. Furthermore, additional com- pounds such as organic carbon further contribute to aerosol water following the $\kappa$-approach (Petters and Kreidenweis, 2007). Aerosol water uptake is limited by a relative humidity of $95 \%$ of grid box mean relative humidity. The extinction, single scattering albedo and asymmetry factor are determined with the help of the volume-weighted complex refraction index of the particles assuming an internal mixture of the individual components. This assumption partially influences the absolute values of the calculated AOD (see e.g., Klingmüller et al., 2014, and references therein). Potential impacts can be amplified absorption by soot due to multiple reflection as seen from a detailed core-shell treatment. However, as all simulations use the same assumption of internal mixing, potential trends in AOD should be affected only to a minor degree.

Previous studies using the EMAC model have proven that the simulated AOD is able to capture the overall global pattern, although a general underestimation is present (de Meij et al., 2012b; Pozzer et al., 2012). The seasonal cycle of AOD is in general well represented in the EMAC model simulations in most parts of the globe, especially over dust influenced regions. In heavily anthropogenic polluted regions, the modeled AOD slightly overestimates the observations.

In this study, the chemistry-climate model (CCM) EMAC has been used with a T63L31 resolution, corresponding to a horizontal resolution of $\approx 1.875^{\circ} \times 1.875^{\circ}$ of the quadratic Gaussian grid, and with 31 vertical levels up to $10 \mathrm{hPa}$ in the lower stratosphere. The model set-up used in this work was presented by Pozzer et al. (2012), and here only the differences and the central features are described.

The atmospheric chemistry is simulated with the MECCA (Module Efficiently Calculating the Chemistry of the Atmosphere) submodel by Sander et al. (2005, 2011), while the aerosol microphysics and gas-aerosol partitioning are calculated by the Global Modal-aerosol eXtension (GMXe) aerosol module (Pringle et al., 2010a, b). For descriptions of the emission and deposition routines, we refer to Kerkweg et al. (2006a), Kerkweg et al. (2006b), Pozzer et al. (2006), and Tost et al. (2007).

As in Pozzer et al. (2012) and Pringle et al. (2010a), both dust and sea-salt emissions are offline prescribed using offline monthly emission files based on AEROCOM and do not depend on the model meteorology, hence having no multi-annual variability. However, desert dust and sea salt aerosol concentrations that influence the AOD calculation exhibit multi-annual variability as the model description of the aerosol microphysical process (coagulation, condensation, ageing) as well as transport (advection, convection) and deposition processes are subject to meteorological variability.

The biomass-burning contribution was added using the Global Fire Emissions Database (GFED version 3, van der Werf et al., 2010) with a monthly temporal resolution.

In this work, we used the emissions scenarios recently developed for the ACCMIP (www.giss.nasa.gov/projects/ 
accmip/) initiative, which focuses on emissions scenarios based on the Representative Concentration Pathways (RCPs) (Lamarque et al., 2011; Meinshausen et al., 2011; van Vuuren et al., 2011b, a, and references therein). The RCPs consist of four emission scenarios, also called RCP 2.6, 4.5, 6.0, and 8.5 representing the radiative forcing of anthropogenic activity from 2.6 to $8.5 \mathrm{~W} \mathrm{~m}^{-2}$ in 2100 , which depend on the mitigation or emission scenarios. Among them, the emission scenario RCP 8.5 is used in this study as Granier et al. (2011) showed that it is a "reasonable" choice for anthropogenic emissions after the year 2000 and for the recent past.

In this work, two simulations were performed covering the year 2000-2010:

- a simulation named BASE, where the anthropogenic emissions were based on the RCP 8.5 scenario and the biomass burning were based on the GFED3.1 (Global Fire Emissions Database, Van der Werf et al., 2006; Randerson et al., 2013) emissions (e.g., with annual variability of the emissions);

- a simulation named FIXEMI, where the anthropogenic and biomass-burning emissions were kept constant during all the simulation and equivalent to the year 2000 (i.e., with no interannual variability of the emissions).

Additionally, to compare the different simulations, the chemistry and the dynamics have been decoupled, such that there is no direct interaction and feedback between the atmospheric composition of the gas phase and aerosol particles with the dynamics of the atmosphere.

Accordingly, both simulations follow the same (i.e., binary identical) dynamics and meteorology; i.e., the CCM is used as a chemistry-transport model. The model dynamic has been weakly nudged (Jeuken et al., 1996; Jöckel et al., 2006) towards the analysis data of the European Centre for MediumRange Weather Forecasts' (ECMWF) operational model to represent the actual day-to-day meteorology in the troposphere, which allows a direct comparison of the simulations results with observations.

Although the simulations cover the period 2000-2010, the first year is used as spinup time, and the results of this work are based on 10 years of data (2001-2010). Additionally, the submodel SORBIT (Jöckel et al., 2010) was used to sample the AOD at the correct local time of the satellite overpass. Hence, we can neglect any influence of the diurnal cycle in the comparisons performed in the next sections.

\section{Remote sensing data}

In this work, observations from three different satellite sensors have been analyzed independently. Specifically, the following satellite data sets have been used:

- The Multi-angle Imaging SpectroRadiometer (MISR) instrument (Diner et al., 1998) is located onboard the
Terra satellite and has been operational since February 2000. The instrument is designed to measure the solar radiation reflected by the Earth-atmosphere system by a multiple camera configuration (four forward, one nadir, and four backward at viewing angles of 70.5, $60.0,45.6,26.1$, and $0^{\circ}$ ). Each camera measures in four different wavelengths centered at $446 \mathrm{~nm}$ (blue), $558 \mathrm{~nm}$ (green), $671 \mathrm{~nm}$ (red) and $866 \mathrm{~nm}$ (near-infrared). MISR data are acquired at $0.275 \times 0.275 \mathrm{~km}^{2}$ and $1.1 \times 1.1 \mathrm{~km}^{2}$ and aerosol products are derived at $17.6 \times 17.6 \mathrm{~km}^{2}$ resolution. There is a time difference of $7.5 \mathrm{~min}$ between the first and the last camera to view the exact geographic position as the satellite flies over. Each path has a swath width of $360 \mathrm{~km}$ with a 16-day repeat cycle. In this study, Level 3 Component Global Aerosol Product version F15 (CGAS-F15) data are used. Specifically the AOD (aerosol optical depth) retrievals at $558 \mathrm{~nm}$ from the level 2 product are averaged on a monthly basis and stored on a geographic grid of $0.5^{\circ} \times 0.5^{\circ}$. The validation of MISR AODs over land and ocean with AERONET (AErosol RObotic NETwork) data has shown that MISR retrievals are within \pm 0.05 or $\pm 20 \%$ of that of AERONET (Kahn et al., 2005, 2010).

- The Moderate Resolution Imaging Spectroradiometer (MODIS) sensor is also located on the Terra satellite. In contrast to MISR, the MODIS instrument has only one nadir-looking camera which measures radiances in 36 spectral bands, from $0.4-14.5 \mu \mathrm{m}$, with spatial resolutions of $250 \mathrm{~m}$ (bands 1-2), $500 \mathrm{~m}$ (bands 3-7) and $1000 \mathrm{~m}$ (bands 8-36). Daily level 2 (MOD04) aerosol optical thickness data are produced at the spatial resolution of $10 \times 10 \mathrm{~km}$ over land, aggregated from the original $1 \times 1 \mathrm{~km}$ pixel size. As the swath width is about $2330 \mathrm{~km}$, the instrument has almost a daily global coverage. MODIS aerosol products are provided over land (Kaufman et al., 1997) and water surfaces (Tanré et al., 1997) with uncertainties being $\pm 0.05 \pm 0.15 \times$ AOD (Chu et al., 2002; Remer et al., 2008; Levy et al., 2010) and $\pm 0.03 \pm 0.05 \times$ AOD (Remer et al., 2002, 2005), respectively. In this paper, AOD550 data from the MODIS level 3 (Col. 051) gridded product are used at a spatial resolution of $1^{\circ} \times 1^{\circ}$. In this work the Deep Blue algorithm products was not used, as does not present any coverage after the year 2007 in this MODIS version. Nevertheless, this algorithm allows retrieval from bright surfaces and therefore could allow a full coverage also over desert area (Sayer et al., 2013).

- The SeaWIFS (Sea-viewing Wide Field-of-view Sensor) instrument operated on board GeoEye's OrbView-2 (AKA SeaStar) satellite providing data from September 1997 to December 2010. AODs at different wavelengths have been retrieved over land with the use of the Deep Blue algorithm over land (Hsu et al., 2004, 2006) and ocean using the SeaWiFS Ocean Aerosol Retrieval 
(SOAR) algorithm (Sayer et al., 2012a) at a horizontal resolution of $\sim 13.5 \mathrm{~km}$. Here, SeaWiFS v004 level 3 AOD550-gridded data are used at a spatial resolution of $1^{\circ} \times 1^{\circ}$ following (Hsu et al., 2012). Validation studies of SeaWIFS' AOD550 with ground-based observations from AERONET and data from other satellite sensors indicate an absolute expected error of $\pm 0.03 \pm 15 \%$ over ocean and $\pm 0.05+ \pm 20 \%$ over land at $550 \mathrm{~nm}$ (Sayer et al., 2012a, b).

In addition to the satellite observations, AOD from station observations are also used in this work. The AOD observations have been obtained from the global AErosol RObotic NETwork (AERONET Holben et al., 1998; Dubovik et al., 2000). The solar extinction measurements are used to calculate the aerosol optical depth with an accuracy of about \pm 0.01 AOD units (Eck et al., 1999). The cloud-screened quality-assured level 2 AOD data used in this work were obtained from the website http://aeronet.gsfc.nasa.gov/cgi-bin/ combined_data_access_new, and contain AOD daily averages. Furthermore, the AOD at $550 \mathrm{~nm}$ was calculated from the AOD values reported at 870 and $440 \mathrm{~nm}$ by using the information of the Angström exponent (see Eqs. 1 and 2, de Meij et al., 2012b).

\section{Model evaluation and AERONET observations comparison}

The model AOD product was extensively evaluated already in a number of publications (Pringle et al., 2010a; de Meij et al., 2012b; Pozzer et al., 2012; Astitha et al., 2012). Important for this work is the study of Pringle et al. (2010b), which used the same water uptake coefficients used here. Pringle et al. (2010b) has shown that there is both qualitatively and quantitatively good agreement of aerosol hygroscopicity (and hence water uptake) with measurement campaigns all over the world. Pringle et al. (2010b) included comparison of the modeled values with surface concentrations and vertical profiles (available from several campaigns). This agreement provides us with confidence that the representation of water uptake of the aerosol particles in the model is sufficiently credible to draw conclusions from temporal trends.

In this section, we therefore compare briefly the model with AERONET observations to confirm the previous findings. Additionally, in this work the AERONET data are purely used for evaluation of the model performance, but no AOD trends will be estimated and compared with the model, as this was already performed by de Meij et al. (2012b).

As shown in Fig. 1, the model reproduces the AOD observed by AERONET within a factor of 2 in 73.5 and $72.9 \%$ of the cases for BASE and FIXEMI, respectively. When the observed AODs are compared to the simulated AODs, it is interesting to notice that both simulations show similar linear fit: the correlation coefficients $(0.57$ and 0.52 for BASE and FIXEMI, respectively) and the bias (0.02 and 0.03 for

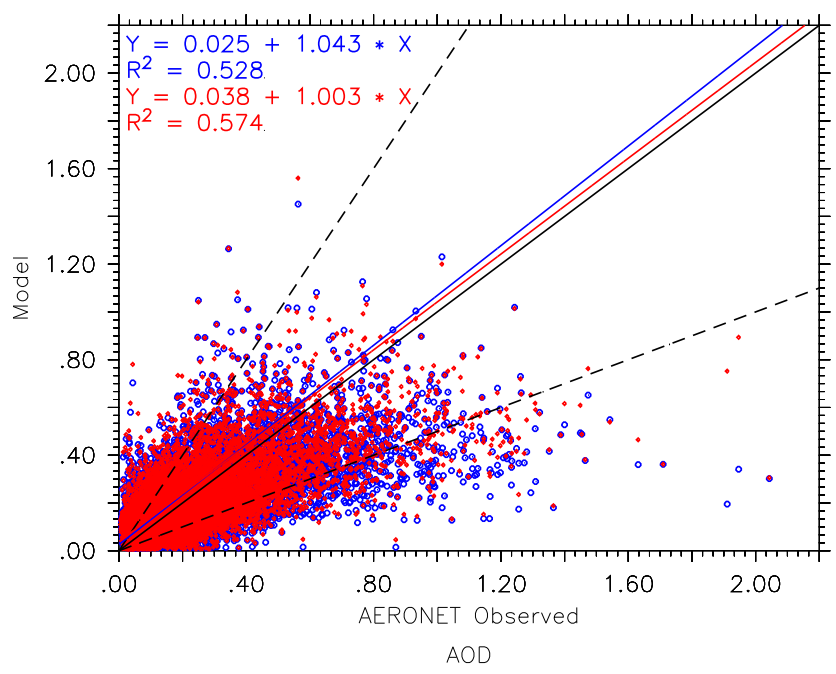

Figure 1. Scatter plot of observed (AERONET) and simulated daily AOD. The model is sampled in the same temporal/spatial location of the observations. The colored lines represent the linear fit, with the coefficient listed in the figure: blue - model results from simulation FIXEMI; red - model results from simulation BASE.

BASE and FIXEMI, respectively) are very similar while the slope is almost equal to 1 for both simulations. This implies that the average global observed and calculated AODs do not vary significantly during 2001 and 2010, which corroborates the study by Chin et al. (2014). It also indicates that both simulations are in general able to reproduce the overall max$\mathrm{ima} /$ minima, although BASE shows slightly better agreement for correlation and slope of the linear fit. However, large differences are found in the AOD trends on a regional scale between BASE and FIXEMI, and this will be further discussed in the next sections.

\section{AOD trends}

\subsection{AOD trends - geographic patterns}

In Fig. 2 the global trends observed by MODIS, MISR and SeaWIFS instruments are shown. A simple linear model has been applied to estimate the trends following the work of (Weatherhead et al., 1998): $Y_{\mathrm{t}}=\mu+\omega X_{\mathrm{t}}+S_{\mathrm{t}}+N_{\mathrm{t}}$, where $Y_{\mathrm{t}}, \mu, \omega$ and $X_{\mathrm{t}}$ denote the monthly time series, the offset, the trend (i.e., AOD $\left.\mathrm{yr}^{-1}\right)$, and the years of the time series $\left(X_{\mathrm{t}}=\right.$ $t / 12$ with $t$ as month), respectively. $S_{\mathrm{t}}$ is a seasonal component representing the effect of the seasonal variations in the trends estimates, while $N_{\mathrm{t}}$ is the residual term of the interpolation. The seasonal component we have taken into account is based on the Fourier series as proposed by Weatherhead et al. $(1998,2002)$ with $S_{\mathrm{t}}=\sum_{j=1}^{4}\left[\beta_{1, j} \sin (2 \pi j t / 12)+\right.$ $\left.\beta_{2, j} \cos (2 \pi j t / 12)\right]$. A statistically significant trend at $95 \%$ confidence level is defined by the absolute value of the ratio of the trend to its standard deviation which is larger than two 

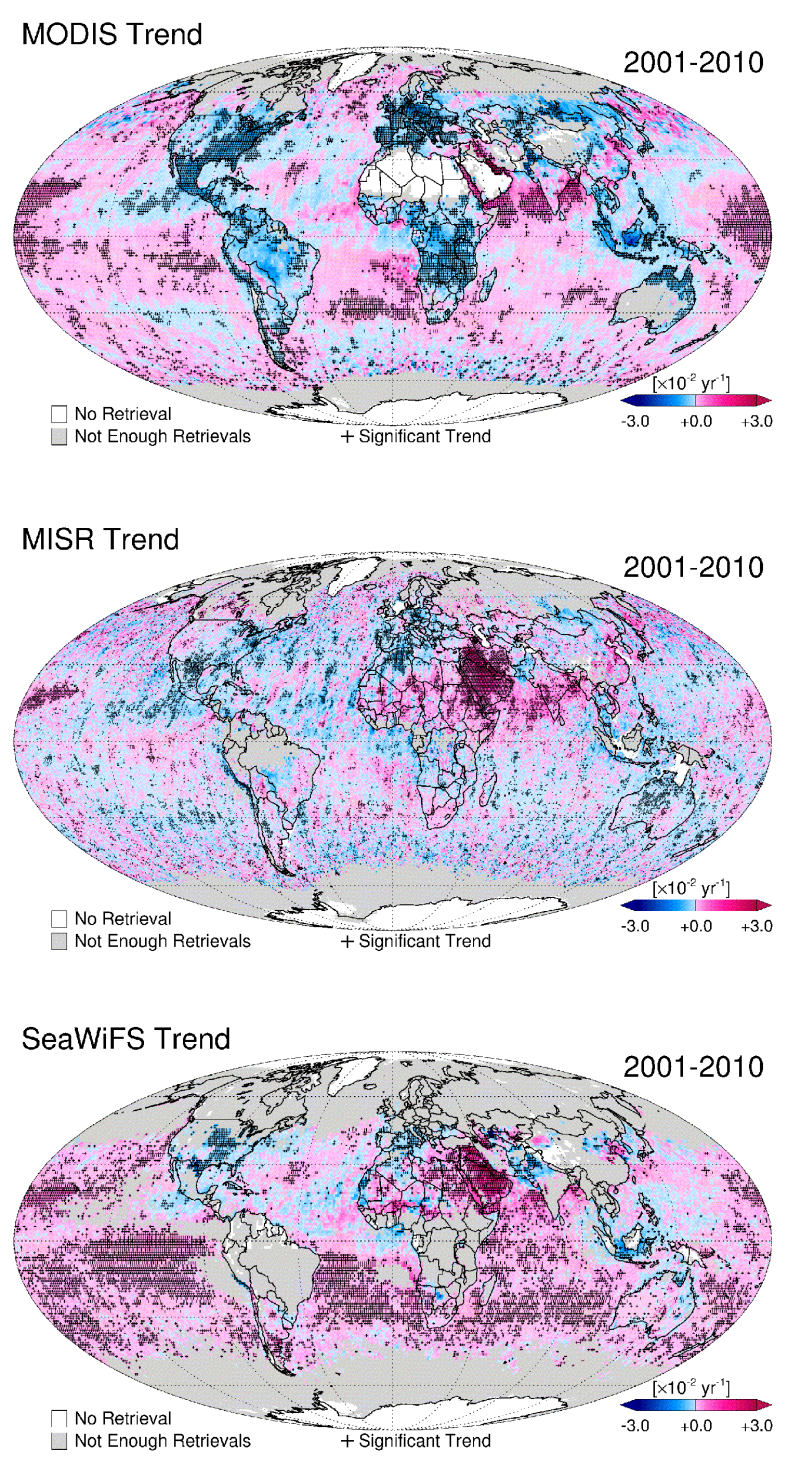

Figure 2. Linear trend between 2001 and 2010 in $10^{-2}$ year $^{-1}$ from different satellite instrument. The gray area means that less than six observations for each year were present, while white area means that not retrieval is present. Locations with trend significant at the $95 \%$ level are covered with the + symbol.

(Tiao et al., 1990; Weatherhead et al., 1998), with the standard deviation of the trend estimated again with the approach of Weatherhead et al. (1998, Eq. 2). Finally, no trends were calculated for locations with less than six data points for each year between 2001 and 2010 (gray area in Fig. 2).

It is clear that trends from monthly averages of level 3 data should be interpreted with caution, as the monthly averages are calculated independently of the representativeness of the data sampled. The sampling of actual retrievals is highly nonuniform in space and time, even at the resolution of the products used in this work (Kahn et al., 2009). Therefore, especially in the case of locations with very high frequencies of cloud-covered sky, the monthly averages could be calculated based on the value of few observations for each month.

As already shown by de Meij et al. (2012a), "significantly negative trends are present over Europe and North America, whereas over South and East Asia they are mostly positive". More specifically, both MISR and SeaWIFS show a significant decrease over North America and part of Europe that is smaller than what was observed by MODIS. A strong, significant increase is instead visible over Saudi Arabia for both MISR and SeaWIFS. MODIS presents a much better spatial coverage (due to the almost daily global coverage), showing a strong reduction of the AOD in the decade 2001-2010 especially over the eastern US, Europe, and biomass-burning regions, such as central Africa and Southeast Asia. The southern Arabian peninsula shows a significant increasing trend, although this is not shown directly by MODIS, as the standard Dark Target product does not present aerosol information over bright surfaces, such as deserts and ice. Although the Deep Blue algorithm corrected this deficiency, no data are available after the year 2007 in the version of the MODIS data used in this work; therefore no trends can be calculated from the MODIS Deep Blue data set and this product is not used in this work.

In Fig. 3 the trends are estimated for both simulations (FIXEMI and BASE), using the same method as for the remote-sensed observations. For both model simulations, AOD data are sampled at the same co-located time of the observations, thanks to the submodel SORBIT (Sample along satellite ORBIT, Jöckel et al., 2010), following the trajectories of the platform TERRA (on which MODIS and MISR instruments are on board) and OrbView-2 (with the SeaWIFS instrument on board).

The model presents some discrepancies on developing region and over regions strongly influenced by biomass burning. On the other side, the sign of the trends is correctly reproduced over North America and Europe. The tendencies over North America and Eastern Europe are consistent with the results of various studies based on trend analysis of satellite-retrieved AOD (e.g., Zhang and Reid, 2010; Hsu et al., 2012; Yoon et al., 2014). Since the satellite-retrieved AOD data, which have been used in most of the trend analyses, are only available under cloud-free conditions, the trend estimates based on the cloud-free AOD products can be biased due to insufficient retrievals in cloudy seasons (Yoon et al., 2014). It must also be underlined that the simulation data are not screened for cloudy conditions, as is done for the satellite data, but represent aerosol optical properties at all times. However, due to the relative-humidity-limited aerosol water uptake, a large overestimation of AOD due to the high water available for aerosol growth in cloudy conditions is not expected. Nevertheless, the cloudy conditions contribute to AOD values at the upper edge of the extinction probability density function.

In the model results, a significant increase of AOD both in simulations BASE and FIXEMI can also be observed over 

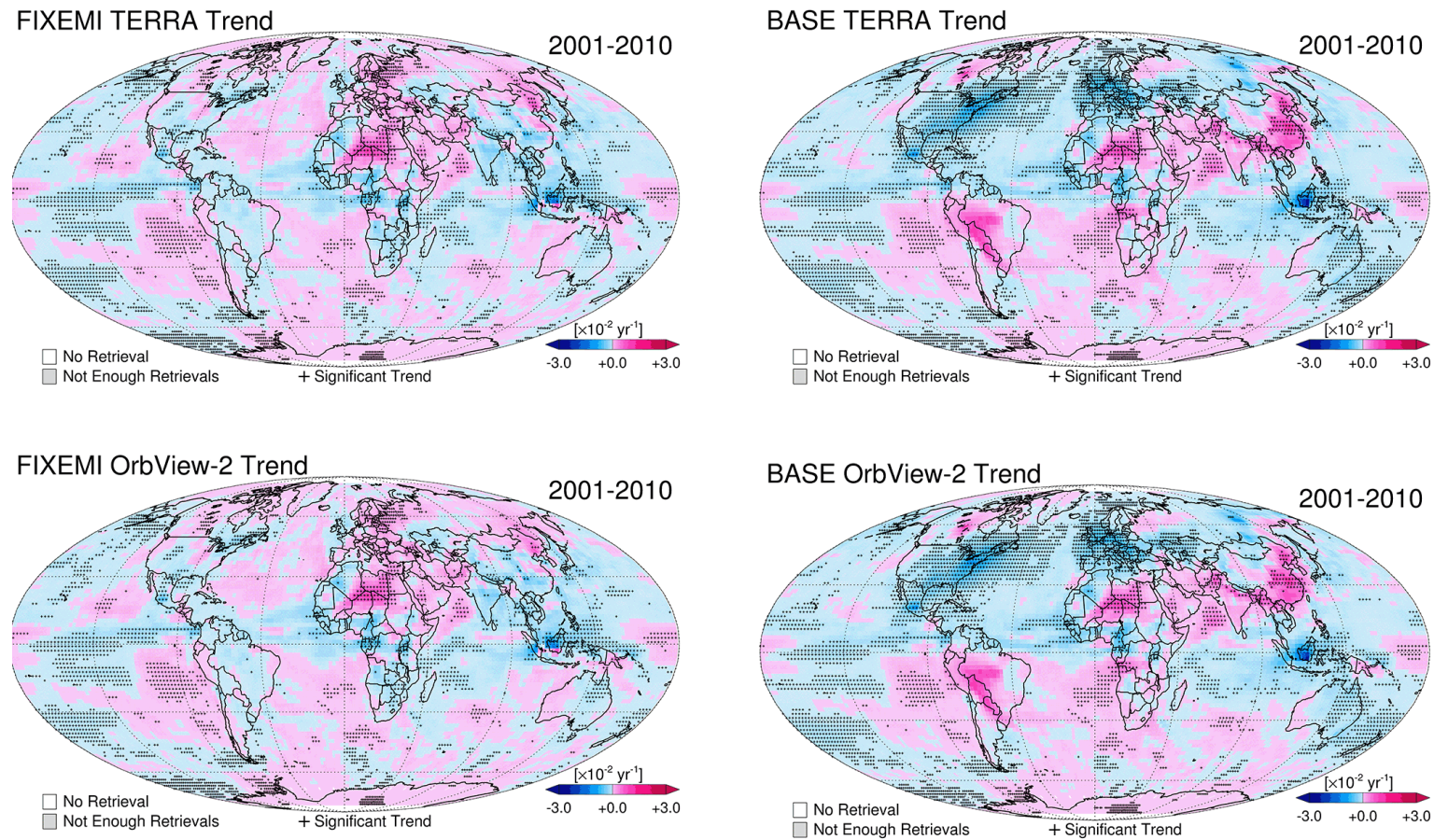

Figure 3. Linear trend between 2001 and 2010 in $10^{-2}$ year $^{-1}$ for simulations FIXEMI and BASE (left and right column respectively) estimated using the output of the submodel SORBIT, i.e., at the correct overpass time of the TERRA and OrbView-2 platform.

the Arabian peninsula; this was confirmed by the observations. In addition, a strong significant increase during the decade 2001-2010 is observed over East Asia, which is however not fully corroborated by the observations. The strong decreasing trend over the tropical/southern Africa is not well reproduced by the model.

The model results from simulation data FIXEMI (see Fig. 3, left plots) do not show significant trends both in Europe and the northern US, while they still do present significant trends both in northern Africa (Sahara Desert) and Southeast Asia.

Discrepancies between simulation BASE and MODIS observations are clearly observed in central Africa and South America. Nevertheless this is not corroborated by other satellite observations. On the contrary, both MISR and SeaWiFS present in this region not enough observations to estimate a trend. This points out the large effect that clouds have on these regions and the possible influence on the remote-sensed data. Therefore these regions will not be analyzed in detail, as observational data sets could be contaminated (Yoon et al., 2012).

\subsection{AOD regional trends}

The global analysis of the AOD trends discussed in the previous section revealed regions of interest where the trends from either satellite instruments or model simulation BASE are significant and require further investigation. The seven se-

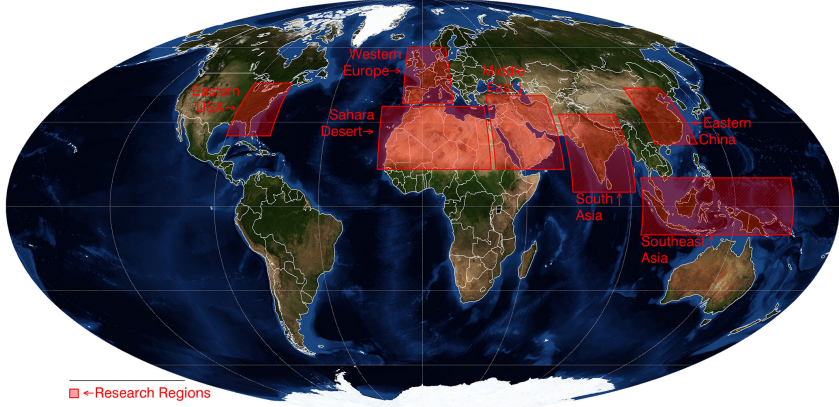

Figure 4. Regions used in this work.

lected regions are eastern United States (EUS), western Europe (WE), Sahara Desert (SD), the Middle East (ME), South Asia (SA), eastern China (EC), and Southeast Asia (SEA) (illustrated in Fig. 4). In addition, three more regions have been included for completeness, i.e., the Northern Hemisphere (NH), Southern Hemisphere (SH), and the whole globe (GL).

The regional trend analysis is illustrated with scatter plots that show the comparison between the model and the satellite AOD trends (Fig. 5), each point representing the regional mean trend for the respective regions. Additionally, temporal time series both for observations and model results are included in the Supplement, together with trends estimated for different meteorological parameter particularly relevant. 

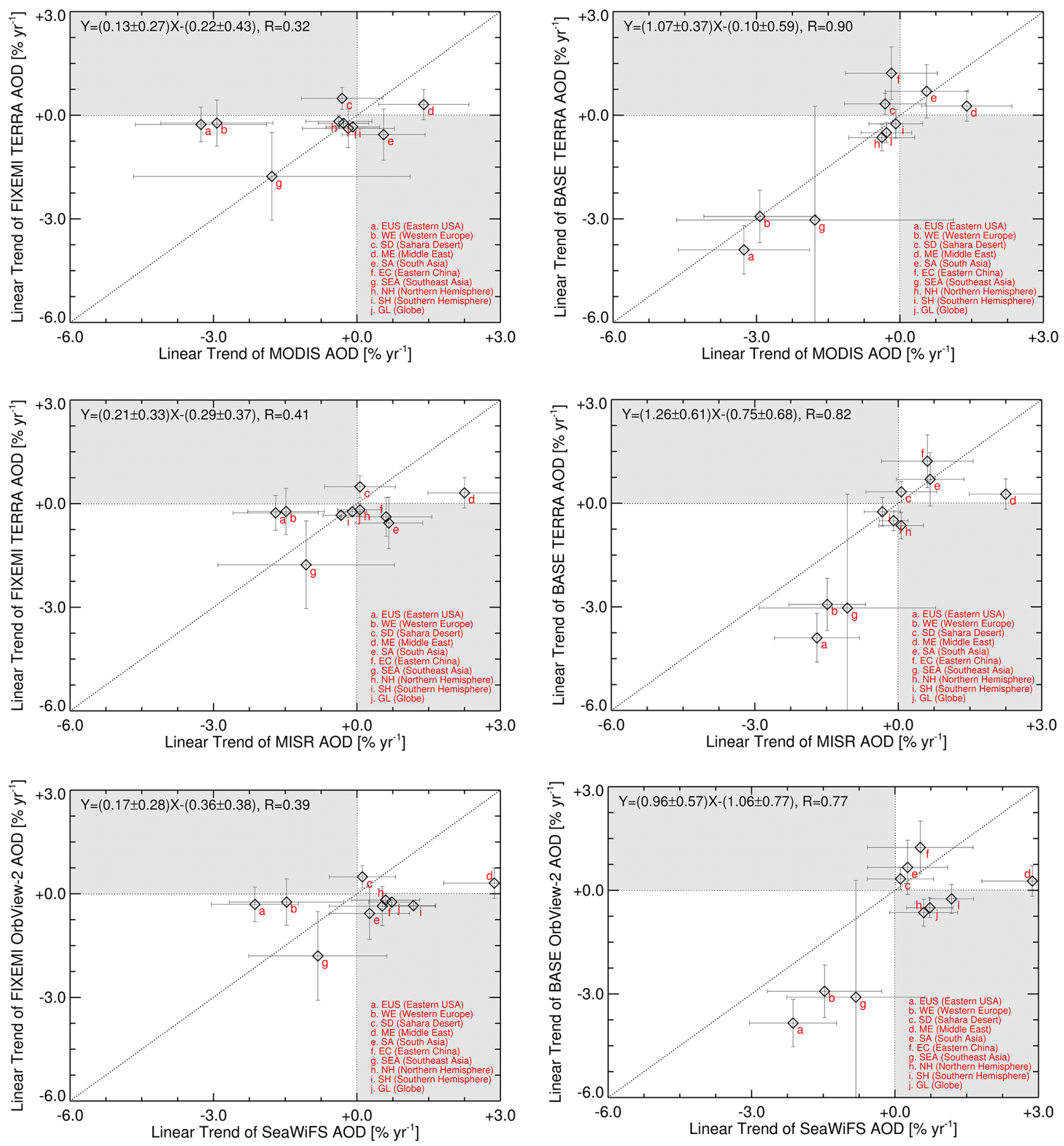

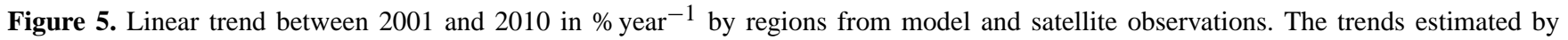
observations are on the $x$ axis. The trends estimated by simulations are on the $y$ axis. The letters define the regions. The bars represent the $2 \sigma$ (i.e., 2 standard deviations) of the trends: top - data from MODIS data set; middle - data from MISR data set; bottom - data from the SeaWiFS data set; left - data from simulation FIXEMI; right - data from simulation BASE.

The two model simulations (FIXEMI, BASE) are equally important in investigating the effect of decadal emission changes during 2001-2010. By comparing the two model simulations, we obtain useful information about the con- tribution of the emissions to the positive or negative AOD trends. The first evident conclusion is that the trends calculated from the BASE simulation (varying emissions) compare well with the satellite trends in contrast with the FIX- 
EMI simulation (constant emissions). The correlation coefficients for the BASE-satellite trends range between 0.73 and 0.87 , whereas for the FIXEMI the values are significantly lower (0.32-0.41). This result alone gives a first insight on the importance of the emissions variation of the AOD within the time period under analysis.

Focusing on the target regions, over western Europe (WE) the AOD trends are negative by the model simulations and the satellite retrievals, with BASE being closer to the satellite-based trend. This is related to the influence of the anthropogenic emissions regulation imposed in western Europe that resulted in a decrease of the atmospheric aerosol load during the decade 2001-2010 (Vestreng et al., 2007, 2009). The same applies to the eastern US (EUS) with results by simulation BASE and observed AOD having a negative trend. Nevertheless, the model overestimates the negative trend by MISR and SeaWIFS and correlates better with the MODIS retrievals.

A common pattern appears in the AOD trends for the climatically sensitive region of the Middle East (ME) by the model simulations and satellite data. The positive trends calculated from the observations (the three satellite products agree) are somewhat higher than predicted by the model, which shows a slightly positive trend in both simulations (BASE and FIXEMI). This means that the variation in the anthropogenic and biomass-burning emissions did not affect the AOD trend in this region, (see FIXEMI results) which is mostly affected by desert dust emissions and the dynamic factors that control dust transport and deposition. Moreover, the dust emissions were prescribed off-line in the model, i.e., independent of the wind fields and therefore independent of the meteorological conditions and without any interannual variability. Therefore, the positive trends in this region can be attributed to the decrease in the precipitation and the consequent reduction of wet scavenging of dust particles, phenomena already observed by several authors for the decade 2001-2010 (e.g., Shehadeh and Ananbeh, 2013; Philandras et al., 2011).

The latest is confirmed by the precipitation trends calculated from the model results, which is shown in Fig. 6. Clearly the region over North Africa presents negative precipitation trends which influence the dust deposition and its transport. Further confirmation is by the Global Precipitation Climatology Project (GPCP), which shows a strong decrease in precipitation over the Middle East during the period 20072010 (not shown). Finally, despite the increasing AOD trend in the region simulated by the model, this is still lower than what is estimated by the observations, due to (i) the constant emissions which do not include enough variability in the source areas (Astitha et al., 2012), and (ii) lower precipitations decrease in the model simulations than the observed one for the period 2007-2010.

The same behavior is found for the Sahara Desert (SD) region, where the AOD trends remain unchanged between the two model simulations (i.e., implying a meteorological

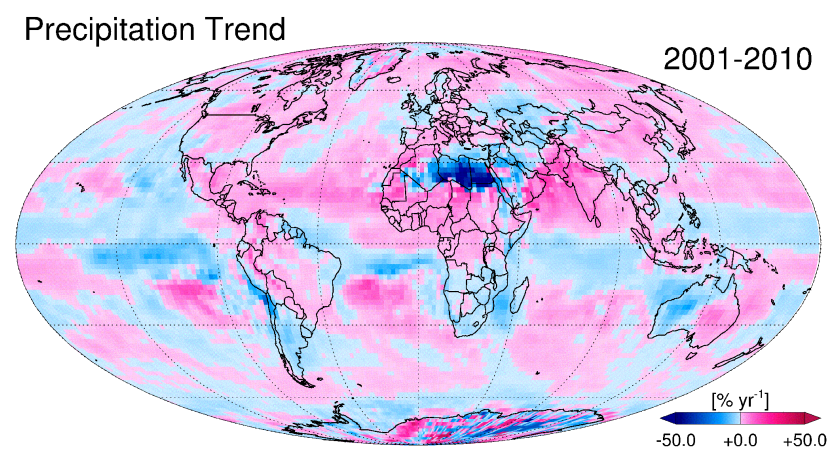

Figure 6. Linear trend in $\%$ year $^{-1}$ for surface precipitation in both simulations BASE and FIXEMI.

driven trend), which can be attributed to the decrease precipitation over North Africa (see Fig.6). The trends observed by the satellites exhibit a small variation (for MODIS it is slightly negative; for MISR and SeaWIFS it is slightly positive) which can be attributed to the different algorithm assumptions (Kahn et al., 2007, 2009), calibration methods, and differences in the aerosol models used to construct the lookup tables in the retrieval algorithms (Abdou et al., 2005). Nevertheless, the difference in the trends is very small considering the high total AOD values in this region.

For South Asia (SA) and eastern China (EC), the improved temporal correlation coefficients by the BASE simulations with the satellite trends shows the importance of the variability in the emissions compared to the constant emission assumption. The sign of the trend changes from negative (FIXEMI) to positive (BASE) in the two simulations, which is due to the increased emissions of the fast-developing countries like China and India. The high positive trends modeled by simulation BASE over EC deviate from the satellite trends; this can be explained by the influence of desert dust aerosols that is not accurately represented by the model simulations. In fact, the MODIS trends for the entire EC region are slightly negative, whereas the sign is positive by both MISR and SeaWIFS (see Fig. 5). This could be attributed to uncertainties in the AOD retrieval, e.g., sensor calibration status, retrieval accuracy, and cloud contamination. In addition, insufficient sampling not reflecting actual data population due to different sampling times, limited orbital periods, and cloud occurrence, which can be serious over polluted and cloudy areas, could be another reason for differences between the trends estimated from satellite observational data sets (see Yoon et al., 2012, 2014).

In Southeast Asia (SEA), the model (sampled on the TERRA platform overpass) calculated a statistically significant negative trend in FIXEMI $\left(-1.77 \pm 0.6 \% \mathrm{yr}^{-1}\right)$ caused by changes in the meteorological conditions. Interestingly, this trend is enhanced in BASE $\left(-3.03 \pm 1.65 \% \mathrm{yr}^{-1}\right.$, not significant) due the decrease of biomass -burning emissions (Yoon and Pozzer, 2014) during this decade in the region. 


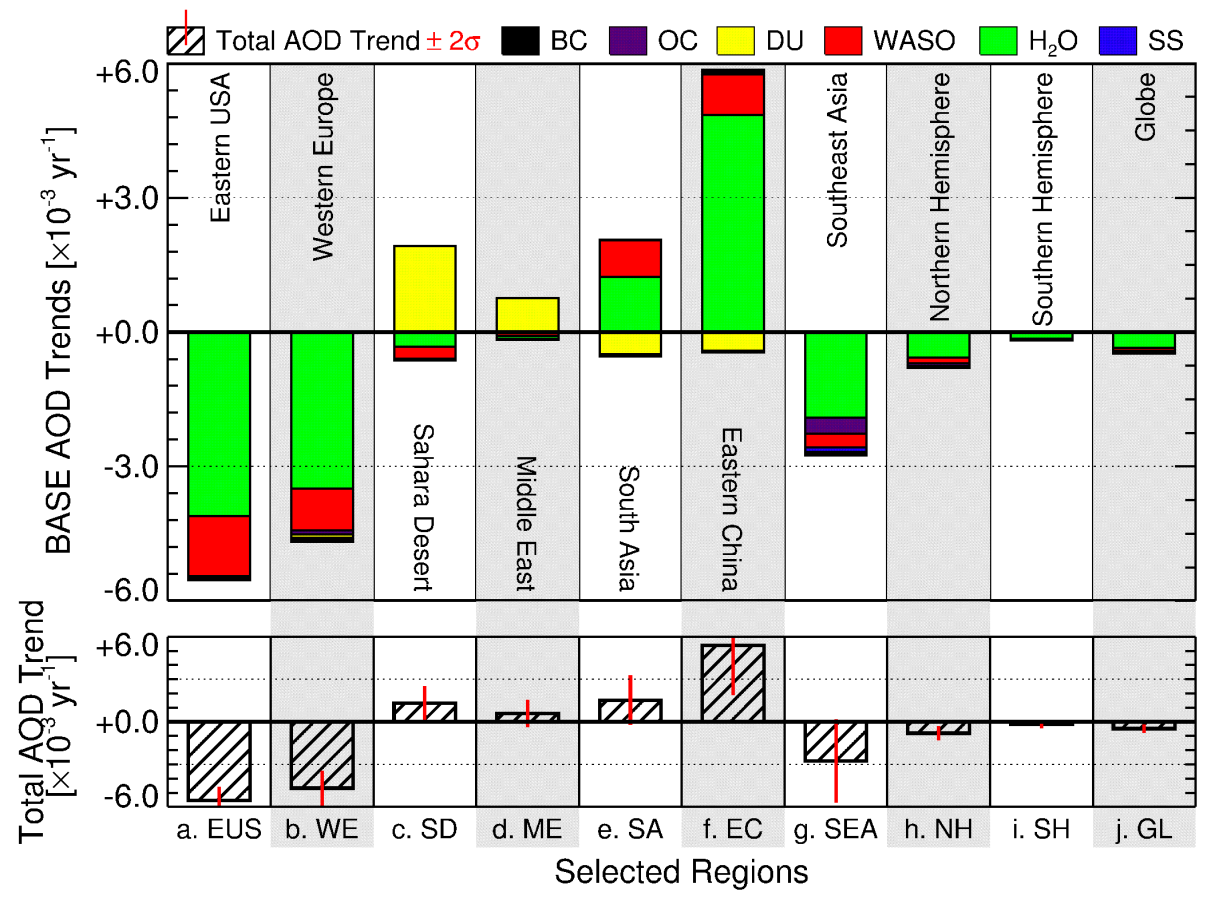

Figure 7. AOD changes between 2001 and 2010 for different regions and species calculated from model results of simulation BASE. The error bars depict 2 standard deviations.

Therefore, AOD trend in this region seems to be caused both by meteorological and emissions changes during the decade.

Finally, the model presents a significant negative trend in the in the Northern Hemisphere (NH) and globally (GL). These trends are also calculated for MODIS and MISR instruments for the same regions, although the results are not significant. Interestingly, in the simulation FIXEMI, no significant trend is detected for the $\mathrm{NH}$, which is emissions driven, while a significant decrease is estimated for the Southern Hemisphere (SH) and globally (GL).

\section{Effects of aerosol components in modeled AOD trends}

In this section, the main causes of positive/negative trends in the regions of interest are analyzed. The trends for each of the regions defined in Sect. 5.2 are decomposed by estimating the AOD trends for the different aerosol components (see Fig. 7 and Table 1): black carbon (BC), organic carbon (OC), dust (DU), aerosol water $\left(\mathrm{H}_{2} \mathrm{O}\right)$, sea salt (SS) and water soluble compounds (WASO, i.e., all water soluble inorganic ions). Additionally, in this section, the full model output was used, so that the results are based on the full 10-year model results.

In general, aerosol water content has the largest contribution to the total AOD with the notable exception of desert area where dust dominates and therefore must be considered as the most effective extinction component in the aerosol pol- luted atmosphere (Gao, 1996). De Meij (2012b) found that over Europe and North America, the associated aerosol water contributes around $40-45 \%$ to the total AOD.

In the eastern part of the US and in the western part of Europe, a decrease in the WASO components (i.e., ammonium, nitrate, and sulphate) is found during the decade 2001-2010. Additionally, since the aerosol water uptake efficiency and consequently, the aerosol water content is decreased by the decrease presence of the WASO components, the negative AOD trends are further amplified. This highlights the fact that the observed AOD trends depend on the reduction in the emissions (van Vuuren et al., 2007; Vestreng et al., 2007, 2009), but also on the nature of the aerosols. The WASO$\mathrm{H}_{2} \mathrm{O}$ relationship was analyzed by de Meij et al. (2012b), both for the EMAC model and the observations for different regions. They showed that, in Europe, the WASO aerosol contributes about $37 \%$ to the yearly mean and the associated aerosol water $45 \%$, respectively. In North America the inorganic part contributes 30 to $40 \%$ to the total AOD and the associated aerosol water $40 \%$.

Over SD and the ME the positive AOD trends are mainly caused by an increase of the natural dust. The WASO components reduce the total AOD trends in these regions due to the lower anthropogenic aerosol transport from Europe into this region. This results in a lower aerosol water content which also reduces the total AOD trends. The increase of the natural dust component to the total AOD does not only compensate for this reduction but also exceeds it, causing, as mentioned before, an overall positive trend over the desert-covered re- 
Table 1. Regional trend estimates of BASE-based AODs, i.e., total, black carbon (BC), organic carbon (OC), dust (DU), water soluble (WASO), $\mathrm{H}_{2} \mathrm{O}$, and sea salt AODs, in $10^{-3}$ year $^{-1}$. One standard deviation is also shown. Bold type indicates the significant trend within $95 \%$ of confidence levels.

\begin{tabular}{lrrrrrrr}
\hline Region & total & BC & OC & DU & WASO & $\mathrm{H}_{2} \mathrm{O}$ & SS \\
\hline (a) EUS & $\mathbf{- 5 . 5 4 2} \pm \mathbf{0 . 4 8 9}$ & $\mathbf{- 0 . 0 3 4} \pm \mathbf{0 . 0 0 2}$ & $-0.033 \pm 0.033$ & $-0.004 \pm 0.019$ & $\mathbf{- 1 . 3 3 7} \pm \mathbf{0 . 1 1 2}$ & $\mathbf{- 4 . 1 1 1} \pm \mathbf{0 . 4 3 4}$ & $-0.022 \pm 0.016$ \\
(b) WE & $\mathbf{- 4 . 6 7 4} \pm \mathbf{0 . 6 1 9}$ & $\mathbf{- 0 . 0 4 2} \pm \mathbf{0 . 0 0 3}$ & $\mathbf{- 0 . 0 9 8} \pm \mathbf{0 . 0 1 6}$ & $-0.065 \pm 0.282$ & $\mathbf{- 0 . 9 2 3} \pm \mathbf{0 . 1 4 4}$ & $\mathbf{- 3 . 4 9 8} \pm \mathbf{0 . 4 0 8}$ & $\mathbf{- 0 . 0 4 6} \pm \mathbf{0 . 0 1 1}$ \\
(c) SD & $\mathbf{+ 1 . 2 9 9} \pm \mathbf{0 . 6 1 1}$ & $-0.000 \pm 0.002$ & $-0.018 \pm 0.016$ & $\mathbf{+ 1 . 9 2 7} \pm \mathbf{0 . 6 0 9}$ & $\mathbf{- 0 . 2 7 2} \pm \mathbf{0 . 8 8}$ & $-0.325 \pm 0.199$ & $-0.009 \pm 0.006$ \\
(d) $\mathrm{ME}$ & $+0.587 \pm 0.484$ & $\mathbf{+ 0 . 0 0 9} \pm \mathbf{0 . 0 0 1}$ & $\mathbf{- 0 . 0 2 5} \pm \mathbf{0 . 0 0 7}$ & $\mathbf{+ 0 . 7 5 4} \pm \mathbf{0 . 3 1 6}$ & $-0.079 \pm 0.070$ & $-0.070 \pm 0.260$ & $\mathbf{- 0 . 0 0 1} \pm \mathbf{0 . 0 0 1}$ \\
(e) SA & $+1.524 \pm 0.876$ & $+0.011 \pm 0.006$ & $+0.001 \pm 0.040$ & $-0.489 \pm 0.263$ & $\mathbf{+ 0 . 8 1 8} \pm \mathbf{0 . 2 0 9}$ & $\mathbf{+ 1 . 2 3 6} \pm \mathbf{0 . 5 6 4}$ & $\mathbf{- 0 . 0 5 4} \pm \mathbf{0 . 0 2 3}$ \\
(f) EC & $\mathbf{+ 5 . 4 0 3} \pm \mathbf{1 . 7 4 9}$ & $\mathbf{+ 0 . 0 9 9} \pm \mathbf{0 . 0 1 7}$ & $+0.012 \pm 0.121$ & $\mathbf{- 0 . 4 1 0} \pm \mathbf{0 . 1 8 8}$ & $\mathbf{+ 0 . 8 9 7} \pm \mathbf{0 . 3 1 7}$ & $\mathbf{+ 4 . 8 5 0 \pm 1 . 4 8 8}$ & $\mathbf{- 0 . 0 4 6} \pm \mathbf{0 . 0 1 5}$ \\
(g) SEA & $-2.753 \pm 1.474$ & $-0.050 \pm 0.037$ & $-0.363 \pm 0.301$ & $\mathbf{- 0 . 0 2 7} \pm \mathbf{0 . 0 1 2}$ & $-0.300 \pm 0.197$ & $\mathbf{- 1 . 9 0 7} \pm \mathbf{0 . 9 1 1}$ & $\mathbf{- 0 . 1 0 4} \pm \mathbf{0 . 0 3 5}$ \\
(h) NH & $\mathbf{- 0 . 7 9 8} \pm \mathbf{0 . 2 4 7}$ & $\mathbf{- 0 . 0 0 5} \pm \mathbf{0 . 0 0 2}$ & $\mathbf{- 0 . 0 6 2} \pm \mathbf{0 . 0 3 0}$ & $-0.018 \pm 0.037$ & $\mathbf{- 0 . 1 2 6} \pm \mathbf{0 . 0 3 8}$ & $\mathbf{- 0 . 5 6 5} \pm \mathbf{0 . 1 6 6}$ & $\mathbf{- 0 . 0 2 0} \pm \mathbf{0 . 0 0 4}$ \\
(i) SH & $-0.164 \pm 0.139$ & $+0.001 \pm 0.003$ & $+0.009 \pm 0.033$ & $-\mathbf{0 . 0 1 7} \pm \mathbf{0 . 0 0 5}$ & $+0.013 \pm 0.029$ & $-0.143 \pm 0.075$ & $\mathbf{- 0 . 0 2 7} \pm \mathbf{0 . 0 0 4}$ \\
\hline (j) GL & $\mathbf{- 0 . 4 8 1} \pm \mathbf{0 . 1 4 0}$ & $-0.002 \pm 0.002$ & $-0.026 \pm 0.023$ & $-0.018 \pm 0.017$ & $\mathbf{- 0 . 0 5 6} \pm \mathbf{0 . 0 2 2}$ & $\mathbf{- 0 . 3 5 4} \pm \mathbf{0 . 0 9 4}$ & $\mathbf{- 0 . 0 2 4} \pm \mathbf{0 . 0 0 2}$ \\
\hline
\end{tabular}

gions. The decrease of WASO components in these regions, potentially increases the aerosol lifetime due to the missing coating effect (e.g., sulphate particles over dust) which makes the particles less susceptible for wet removal. This effect plays only a minor role here, as the AOD trends in the FIXEMI and BASE simulations are similar, implying that the trends are strongly dominated by meteorological factors, i.e., the decrease in precipitation as described in Sect. 5.2 and shown in Fig. 6.

The simulation with the BASE scenario for SA and EC (see Fig. 7) reveals a reverse situation. The highly soluble WASO components and the water content exhibit a positive AOD trend while the dust component exhibits a negative trend with the overall AOD trend being positive in these two regions. The trends of the WASO components are very similar for the two regions, while the aerosol water content trend over eastern China is nearly 3 times that of South Asia. This is due to the higher relative humidity over eastern China with respect to South Asia ( 73 and $\sim 59 \%$, respectively, for the 2001-2010 average) which causes a more effective water uptake due to the exponential relationship between water uptake and relative humidity.

Finally, over SEA, the negative AOD trends are due to the decrease of all aerosol components (see Table 1). Dust and sea salt, however, show a significant decrease, implying trends driven by meteorological conditions. In particular, this trend is enhanced by the decrease of the aerosol water content (also significant), which is mostly due to the decrease of the highly soluble sea salt. Nevertheless, the BC/OC decrease (due to biomass-burning decrease in the region during the 2001-2010 decade) enhances the negative trends by $\approx 0.4 \times 10^{-3} \mathrm{yr}^{-1}$. Therefore the total trend in this region $\left(\approx 2.75 \times 10^{-3} \mathrm{yr}^{-1}\right)$ is a combination of a meteorological effect and a decrease of the biomass-burning emissions. However, it is unclear what meteorological parameter is driving such a trend in the region. In fact, the only significant detectable trends in the simulation is a decrease of wind speed at the surface (see Supplement), which could possibly decrease the transport of sea salt from the open ocean to this region and consequently the water contribution to the AOD, as sea salt is highly hydrophilic.

Finally, the NH presents a decreasing significant trend $\left(-0.798 \pm 0.24710^{-3} \mathrm{yr}^{-1}\right) 70 \%$ of which caused by the water uptake decrease. Interestingly, on a global scale (GL, see Fig. 7 and Table 1) the same proportion is kept, with water contributing by $73 \%$ to the total (significant) AOD decrease.

\section{Conclusions}

In this work, the AOD was simulated for a period of 10 years (2001-2010) with the EMAC Chemistry General Circulation Model. AODs from AERONET stations were used to evaluate the model results prior to the calculation of the global and regional AOD trends. Satellite retrievals from MODIS, SeaWiFS and MISR have subsequently been used to estimate the AOD trends and compare them with the simulated results. The trends in the aerosol extinction are qualitatively reproduced over North America, Eastern Europe, North Africa, and the Middle East, while some discrepancies are found over other regions. Seven regions of interest are selected to conduct a regional analysis, based on the strength of the signal from both model and satellite AOD trends.

The main objective of this work is to identify the causes of the decadal AOD trends for the designated regions of interest by decomposing the AOD trends into its aerosol components trends. Therefore, two simulations have been performed to address the research objective; one with changing and one with constant emissions, using identical same atmospheric dynamics. The differences between the two simulations show that the observed AOD increases in the model over the Middle East and North Africa are due to meteorological effects as a strong increase in the dust component of the AOD is found in both simulations for those regions. However, these results are obtained without any online dust emissions calculation, but rather with fixed prescribed monthly emissions. Therefore this AOD increase could be enhance or dampened if interactive dust emissions were calculated. Over the east- 
ern US and western Europe, significant decreasing trends are deduced from the model simulation only when realistic, decreasing emissions in the decade 2001-2010 are included. This indicates the strong influence of anthropogenic emissions on aerosol load and the related AOD. Consequently, it can be confirmed that in the eastern US and western Europe, the AOD decrease is purely driven by emissions reduction policies.

For South Asia and eastern China, the AOD trend is positive both from model results and satellite observations. The differences between the two model simulations identify that the AOD is increasing due to a combination of changes in the anthropogenic emissions, and the meteorological conditions in the denoted areas. Finally, for Southeast Asia, the decreasing trends are due to the decrease in the biomass-burning emissions and the meteorological conditions; here, the purely meteorological trend contributes approximately $50 \%$ of the total AOD trend. The role of natural aerosols (i.e., desert dust) has proven to be significant for the Middle East and North Africa and non-negligible for China and South Asia. Future work in this area would include the online production of dust and sea salt emissions during the simulation time in order to identify the effects of meteorology in the dust component AOD by introducing emission variability for both sea salt and dust in the model. Even though the existing parameterizations for emissions of natural species hide a number of uncertainties, the comparison with the AOD trends that results from off-line prescribed inventories will identify the relative importance of the two methods (e.g., if the AOD trend from dust changes significantly). Finally, the use of a newly developed data set of remote-sensed observations (such as the MODIS collection 6) could improve the reliability and agreements of these data sets and decrease artificial trends due to calibration (Lyapustin et al., 2014).

\section{The Supplement related to this article is available online at doi:10.5194/acp-15-5521-2015-supplement.}

Acknowledgements. The authors thank A. Kerkweg and P. Jöckel for their valuable work on the EMAC source codes and M. Penning de Vries for her suggestions. The authors also wish to acknowledge the use of the Ferret program for analysis and graphics in this paper. Ferret is a product of NOAA's Pacific Marine Environmental Laboratory (information is available at http://www.ferret.noaa.gov). The work of A. K. Georgoulias received funding from the European Social Fund (ESF) and national resources under the operational program Education and Lifelong Learning (EdLL) within the framework of the Action "Supporting Postdoctoral Researchers" (QUADIEEMS project) and from the European Research Council under the European Union's Seventh Framework Programme (FP7/2007-2013)/ERC grant agreement no. 226144 (C8 project).
The article processing charges for this open-access publication were covered by the Max Planck Society.

Edited by: P. Stier

\section{References}

Abdou, W. A., Diner, D. J., Martonchik, J. V., Bruegge, C. J., Kahn, R. A., Gaitley, B. J., Crean, K. A., Remer, L. A., and Holben, B.: Comparison of coincident Multiangle Imaging Spectroradiometer and Moderate Resolution Imaging Spectroradiometer aerosol optical depths over land and ocean scenes containing Aerosol Robotic Network sites, J. Geophys. Res., 110, D10S07, doi:10.1029/2004JD004693, 2005.

Andreae, M. O., Jones, C. D., and Cox, P. M.: Strong present-day aerosol cooling implies a hot future, Nature, 435, 1187-1190, 2005.

Astitha, M., Lelieveld, J., Abdel Kader, M., Pozzer, A., and de Meij, A.: Parameterization of dust emissions in the global atmospheric chemistry-climate model EMAC: impact of nudging and soil properties, Atmos. Chem. Phys., 12, 11057-11083, doi:10.5194/acp-12-11057-2012, 2012.

Cao, J., Garbaccio, R., and Ho, M. S.: China's 11th five-year plan and the environment: reducing $\mathrm{SO}_{2}$ emissions, Review of Environmental Economics and Policy, 3, 231-250, 2009.

Chin, M., Diehl, T., Tan, Q., Prospero, J. M., Kahn, R. A., Remer, L. A., Yu, H., Sayer, A. M., Bian, H., Geogdzhayev, I. V., Holben, B. N., Howell, S. G., Huebert, B. J., Hsu, N. C., Kim, D., Kucsera, T. L., Levy, R. C., Mishchenko, M. I., Pan, X., Quinn, P. K., Schuster, G. L., Streets, D. G., Strode, S. A., Torres, O., and Zhao, X.-P.: Multi-decadal aerosol variations from 1980 to 2009: a perspective from observations and a global model, Atmos. Chem. Phys., 14, 3657-3690, doi:10.5194/acp-14-3657-2014, 2014.

Chu, D., Kaufman, Y., Ichoku, C., Remer, L., Tanré, D., and Holben, B.: Validation of MODIS aerosol optical depth retrieval over land, Geophys. Res. Lett., 29, doi:10.1029/2001GL013205, 2002.

Chylek, P., Lohmann, U., Dubey, M., Mishchenko, M., Kahn, R., and Ohmura, A.: Limits on climate sensitivity derived from recent satellite and surface observations, J. Geophys. Res.-Atmos., 112, D24S04, doi:10.1029/2007JD008740, 2007.

de Meij, A., Pozzer, A., and Lelieveld, J.: Trend analysis in aerosol optical depths and pollutant emission estimates between 2000 and 2009, Atmos. Environ., 51, 75-85, doi:10.1016/j.atmosenv.2012.01.059, 2012a.

de Meij, A., Pozzer, A., Pringle, K., Tost, H., and Lelieveld, J.: EMAC model evaluation and analysis of atmospheric aerosol properties and distribution with a focus on the Mediterranean region, Atmos. Res., 114-115, 38-69, doi:10.1016/j.atmosres.2012.05.014, 2012b.

Diner, D., Beckert, J., Reilly, T., Bruegge, C., Conel, J., Kahn, R., Martonchik, J., Ackerman, T., Davies, R., Gerstl, S., Gordon, H., Muller, J.-P., Myneni, R., Sellers, P., Pinty, B., and Verstraete, M.: Multi-angle Imaging SpectroRadiometer (MISR) instrument description and experiment overview, IEEE Geosci. Remote S., 36, 3113-3136, doi:10.1109/36.700992, 1998.

Dubovik, O., Smirnov, A., Holben, B., King, M., Kaufman, Y., Eck, T., and Slutsker, I.: Accuracy assessments of aerosol optical 
properties retrieved from Aerosol Robotic Network (AERONET) Sun and sky radiance measurements, J. Geophys. Res, 105, 9791-9806, 2000.

Eck, T., Holben, B., Reid, J., Dubovik, O., Smirnov, A., O’Neill, N., Slutsker, I., and Kinne, S.: Wavelength dependence of the optical depth of biomass burning, urban, and desert dust aerosols, J. Geophys. Res, 104, 31333-31349, 1999.

Fountoukis, C. and Nenes, A.: ISORROPIA II: a computationally efficient thermodynamic equilibrium model for $\mathrm{K}^{+}, \mathrm{Ca}^{2+}$, $\mathrm{Mg}^{2+}, \mathrm{NH}_{4}{ }^{+}, \mathrm{Na}^{+}, \mathrm{SO}_{4}{ }^{2-}, \mathrm{NO}_{3}{ }^{-}, \mathrm{Cl}^{-}, \mathrm{H}_{2} \mathrm{O}$ aerosols, Atmos. Chem. Phys., 7, 4639-4659, doi:10.5194/acp-7-4639-2007, 2007.

Gao, B.-C.: NDWI - a normalized difference water index for remote sensing of vegetation liquid water from space, Remote Sens. Environ., 58, 257-266, 1996.

Granier, C., Bessagnet, B., Bond, T., D’Angiola, A., van der Gon, H. D., Frost, G. J., Heil, A., Kaiser, J. W., Kinne, S., Klimont, Z., Kloster, S., Lamarque, J.-F., Liousse, C., Masui, T., Meleux, F., Mieville, A., Ohara, T., Raut, J.-C., Riahi, K., Schultz, M. G., Smith, S. J., Thompson, A., van Aardenne, J., van der Werf, G. R., and van Vuuren D. P.: Evolution of anthropogenic and biomass burning emissions of air pollutants at global and regional scales during the 1980-2010 period, Climatic Change, 109, 163-190, 2011.

Hinkelman, L. M., Stackhouse, P. W., Wielicki, B. A., Zhang, T., and Wilson, S. R.: Surface insolation trends from satellite and ground measurements: comparisons and challenges, J. Geophys. Res.-Atmos., 114, D00D20, doi:10.1029/2008JD011004, 2009.

Holben, B. N., Eck, T. F., Slutsker, I., Tanré, D., Buis, J. P., Setzer, A., Vermote, E., Reagan, J. A., Kaufman, Y. J., Nakajima, T., Lavenu, F., Jankowiak, I., and Smirnov, A.: AERONET: federated instrument network and data archive for aerosol characterization, Remote Sens. Environ., 66, 1-16, 1998.

Hsu, N. C., Tsay, S.-C., King, M. D., and Herman, J. R.: Aerosol properties over bright-reflecting source regions, IEEE T. Geosci. Remote, 42, 557-569, 2004.

Hsu, N. C., Tsay, S.-C., King, M. D., and Herman, J. R.: Deep blue retrievals of Asian aerosol properties during ACE-Asia, IEEE T. Geosci. Remote, 44, 3180-3195, 2006.

Hsu, N. C., Gautam, R., Sayer, A. M., Bettenhausen, C., Li, C., Jeong, M. J., Tsay, S.-C., and Holben, B. N.: Global and regional trends of aerosol optical depth over land and ocean using SeaWiFS measurements from 1997 to 2010, Atmos. Chem. Phys., 12, 8037-8053, doi:10.5194/acp-12-8037-2012, 2012.

Jeuken, A., Siegmund, P., Heijboer, L., Feichter, J., and Bengtsson, L.: On the potential assimilating meteorological analyses in a global model for the purpose of model validation, J. Geophys. Res., 101, 16939-16950, 1996.

Jöckel, P., Tost, H., Pozzer, A., Brühl, C., Buchholz, J., Ganzeveld, L., Hoor, P., Kerkweg, A., Lawrence, M. G., Sander, R., Steil, B., Stiller, G., Tanarhte, M., Taraborrelli, D., van Aardenne, J., and Lelieveld, J.: The atmospheric chemistry general circulation model ECHAM5/MESSy1: consistent simulation of ozone from the surface to the mesosphere, Atmos. Chem. Phys., 6, 50675104, doi:10.5194/acp-6-5067-2006, 2006.

Jöckel, P., Kerkweg, A., Pozzer, A., Sander, R., Tost, H., Riede, H., Baumgaertner, A., Gromov, S., and Kern, B.: Development cycle 2 of the Modular Earth Submodel System (MESSy2), Geosci. Model Dev., 3, 717-752, doi:10.5194/gmd-3-717-2010, 2010.
Kahn, R. A., Gaitley, B. J., Martonchik, J. V., Diner, D. J., Crean, K. A., and Holben, B.: Multiangle Imaging Spectroradiometer (MISR) global aerosol optical depth validation based on 2 years of coincident Aerosol Robotic Network (AERONET) observations, J. Geophys. Res., 110, 148-227, doi:10.1029/2004JD004706, 2005.

Kahn, R. A., Garay, M. J., Nelson, D. L., Yau, K. K., Bull, M. A., Gaitley, B. J., Martonchik, J. V., and Levy, R. C.: Satellitederived aerosol optical depth over dark water from MISR and MODIS: comparisons with AERONET and implications for climatological studies, J. Geophys. Res.-Atmos., 112, D18205, doi:10.1029/2006JD008175, 2007.

Kahn, R. A., Nelson, D. L., Garay, M. J., Levy, R. C., Bull, M. A., Diner, D. J., Martonchik, J. V., Paradise, S. R., Hansen, E. G., and Remer, L. A.: MISR aerosol product attributes and statistical comparisons with MODIS, IEEE T. Geosci. Remote, 47, 40954114, 2009.

Kahn, R. A., Gaitley, B. J., Garay, M., Diner, D. J., Eck, T. A. S., and Holben, B.: Multiangle Imaging Spectroradiometer (MISR) global aerosol optical depth validation based on 2 years of coincident Aerosol Robotic Network (AERONET) observations, J. Geophys. Res., 115, 148-227, doi:10.1029/2010JD014601, 2010.

Kaufman, Y. J., Tanré, D., Remer, L. A., Vermote, E. F., Chu, A., and Holben, B. N.: Multiangle Imaging Spectroradiometer (MISR) global aerosol optical depth validation based on 2 years of coincident Aerosol Robotic Network (AERONET) observations, J. Geophys. Res., 102, 17051-17068, doi:10.1029/96JD03988, 1997.

Kaufman, Y. J., Tanré, D., and Boucher, O.: A satellite view of aerosols in the climate system, Nature, 419, 215-223, 2002.

Kerkweg, A., Buchholz, J., Ganzeveld, L., Pozzer, A., Tost, H., and Jöckel, P.: Technical Note: An implementation of the dry removal processes DRY DEPosition and SEDImentation in the Modular Earth Submodel System (MESSy), Atmos. Chem. Phys., 6, 4617-4632, doi:10.5194/acp-6-4617-2006, 2006a.

Kerkweg, A., Sander, R., Tost, H., and Jöckel, P.: Technical note: Implementation of prescribed (OFFLEM), calculated (ONLEM), and pseudo-emissions (TNUDGE) of chemical species in the Modular Earth Submodel System (MESSy), Atmos. Chem. Phys., 6, 3603-3609, doi:10.5194/acp-6-3603-2006, 2006 b.

Kishcha, P., Starobinets, B., Kalashnikova, O., Long, C. N., and Alpert, P.: Variations of meridional aerosol distribution and solar dimming, J. Geophys. Res.-Atmos., 114, D00D14, doi:10.1029/2008JD010975, 2009.

Klingmüller, K., Steil, B., Brühl, C., Tost, H., and Lelieveld, J.: Sensitivity of aerosol radiative effects to different mixing assumptions in the AEROPT 1.0 submodel of the EMAC atmosphericchemistry-climate model, Geosci. Model Dev., 7, 2503-2516, doi:10.5194/gmd-7-2503-2014, 2014.

Lamarque, J., Kyle, G., Meinshausen, M., Riahi, K., Smith, S., van Vuuren, D., Conley, A., and Vitt, F.: Global and regional evolution of short-lived radiatively-active gases and aerosols in the representative concentration pathways, Climatic Change, 109, 191-212, doi:10.1007/s10584-011-0155-0, 2011.

Lauer, A., Eyring, V., Hendricks, J., Jöckel, P., and Lohmann, U.: Global model simulations of the impact of ocean-going ships on aerosols, clouds, and the radiation budget, Atmos. Chem. Phys., 7, 5061-5079, doi:10.5194/acp-7-5061-2007, 2007. 
Lelieveld, J., Barlas, C., Giannadaki, D., and Pozzer, A.: Model calculated global, regional and megacity premature mortality due to air pollution, Atmos. Chem. Phys., 13, 7023-7037, doi:10.5194/acp-13-7023-2013, 2013.

Levy, R. C., Remer, L. A., Kleidman, R. G., Mattoo, S., Ichoku, C., Kahn, R., and Eck, T. F.: Global evaluation of the Collection 5 MODIS dark-target aerosol products over land, Atmos. Chem. Phys., 10, 10399-10420, doi:10.5194/acp-10-10399-2010, 2010.

Long, C. N., Dutton, E. G., Augustine, J., Wiscombe, W., Wild, M., McFarlane, S. A., and Flynn, C. J.: Significant decadal brightening of downwelling shortwave in the continental United States, J. Geophys. Res.-Atmos., 114, D00D06, doi:10.1029/2008JD011263, 2009.

Lu, Z., Streets, D. G., Zhang, Q., Wang, S., Carmichael, G. R., Cheng, Y. F., Wei, C., Chin, M., Diehl, T., and Tan, Q.: Sulfur dioxide emissions in China and sulfur trends in East Asia since 2000, Atmos. Chem. Phys., 10, 6311-6331, doi:10.5194/acp-106311-2010, 2010.

Lyapustin, A., Wang, Y., Xiong, X., Meister, G., Platnick, S., Levy, R., Franz, B., Korkin, S., Hilker, T., Tucker, J., Hall, F., Sellers, P., Wu, A., and Angal, A.: Scientific impact of MODIS C5 calibration degradation and C6+ improvements, Atmos. Meas. Tech., 7, 4353-4365, doi:10.5194/amt-7-4353-2014, 2014.

Meinshausen, M., Smith, S., Calvin, K., Daniel, J., Kainuma, M., Lamarque, J., Matsumoto, K., Montzka, S., Raper, S., Riahi, K., Thomson, A., Velders, G., and van Vuuren, D.: The RCP greenhouse gas concentrations and their extensions from 1765 to 2300 , Climatic Change, 109, 213-241, doi:10.1007/s10584-011-0156z, 2011.

Mishchenko, M. I. and Geogdzhayev, I. V.: Satellite remote sensing reveals regional tropospheric aerosol trends, Opt. Express, 15, 7423-7438, 2007.

Norris, J. R. and Wild, M.: Trends in aerosol radiative effects over China and Japan inferred from observed cloud cover, solar "dimming”, and solar "brightening”, J. Geophys. Res.-Atmos., 114, D00D15, doi:10.1029/2008JD011378, 2009.

Ohmura, A.: Observed decadal variations in surface solar radiation and their causes, J. Geophys. Res.-Atmos., 114, D00D05, doi:10.1029/2008JD011290, 2009.

Petters, M. D. and Kreidenweis, S. M.: A single parameter representation of hygroscopic growth and cloud condensation nucleus activity, Atmos. Chem. Phys., 7, 1961-1971, doi:10.5194/acp-71961-2007, 2007.

Philandras, C. M., Nastos, P. T., Kapsomenakis, J., Douvis, K. C., Tselioudis, G., and Zerefos, C. S.: Long term precipitation trends and variability within the Mediterranean region, Nat. Hazards Earth Syst. Sci., 11, 3235-3250, doi:10.5194/nhess-11-32352011, 2011.

Pinker, R., Zhang, B., and Dutton, E.: Do satellites detect trends in surface solar radiation?, Science, 308, 850-854, 2005.

Pozzer, A., Jöckel, P., Sander, R., Williams, J., Ganzeveld, L., and Lelieveld, J.: Technical Note: The MESSy-submodel AIRSEA calculating the air-sea exchange of chemical species, Atmos. Chem. Phys., 6, 5435-5444, doi:10.5194/acp-6-5435-2006, 2006.

Pozzer, A., Jöckel, P., Tost, H., Sander, R., Ganzeveld, L., Kerkweg, A., and Lelieveld, J.: Simulating organic species with the global atmospheric chemistry general circulation model ECHAM5/MESSy1: a comparison of model results with obser- vations, Atmos. Chem. Phys., 7, 2527-2550, doi:10.5194/acp-72527-2007, 2007.

Pozzer, A., de Meij, A., Pringle, K. J., Tost, H., Doering, U. M., van Aardenne, J., and Lelieveld, J.: Distributions and regional budgets of aerosols and their precursors simulated with the EMAC chemistry-climate model, Atmos. Chem. Phys., 12, 961-987, doi:10.5194/acp-12-961-2012, 2012.

Pringle, K. J., Tost, H., Message, S., Steil, B., Giannadaki, D., Nenes, A., Fountoukis, C., Stier, P., Vignati, E., and Lelieveld, J.: Description and evaluation of GMXe: a new aerosol submodel for global simulations (v1), Geosci. Model Dev., 3, 391-412, doi:10.5194/gmd-3-391-2010, 2010a.

Pringle, K. J., Tost, H., Pozzer, A., Pöschl, U., and Lelieveld, J.: Global distribution of the effective aerosol hygroscopicity parameter for CCN activation, Atmos. Chem. Phys., 10, 52415255, doi:10.5194/acp-10-5241-2010, 2010b.

Ramanathan, V., Crutzen, P., Kiehl, J., and Rosenfeld, D.: Aerosols, climate, and the hydrological cycle, Science, 294, 2119-2124, doi:10.1126/science.1064034, 2001a.

Ramanathan, V., Crutzen, P. J., Lelieveld, J., Mitra, A. P., Althausen, D., Anderson, J., Andreae, M. O., Cantrell, W., Cass, G. R., Chung, C. E., Clarke, A. D., Coakley, J. A., Collins, W. D., Conant, W. C., Dulac, F., Heintzenberg, J., Heymsfield, A. J., Holben, B., Howell, S., Hudson, J., Jayaraman, A., Kiehl, J. T., Krishnamurti, T. N., Lubin, D., McFarquhar, G., Novakov, T., Ogren, J. A., Podgorny, I. A., Prather, K., Priestley, K., Prospero, J. M., Quinn, P. K., Rajeev, K., Rasch, P., Rupert, S., Sadourny, R., Satheesh, S. K., Shaw, G. E., Sheridan, P., and Valero, F.: Indian Ocean Experiment: an integrated analysis of the climate forcing and effects of the great Indo-Asian haze, J. Geophys. Res.-Atmos., 106, 28371-28398, 2001b.

Remer, L., Kleidman, R., Levy, R., Kaufman, Y., Tanré, D., Mattoo, S., Martins, J., Ichoku, C., Koren, I., Yu, H., and Holben, B.: Global aerosol climatology from the MODIS satellite sensors, J. Geophys. Res., 113, D14S07, doi:10.1029/2007JD009661, 2008.

Remer, L. A., Tanré, D., Kaufman, Y. J., Ichoku, C., Mattoo, S., Levy, R., Chu, D. A., Holben, B., Dubovik, O., Smirnov, A., Martins, J. V., Li, R.-R., and Ahmad, Z.: Validation of MODIS aerosol retrieval over ocean, Geophys. Res. Lett., 29, MOD3-1DMOD3-4, doi:10.1029/2001GL013204, 2002.

Remer, L. A., Kaufman, Y. J., Tanré, D., Mattoo, S., Chu, D. A., Martins, J. V., Li, R.-R., Ichoku, C., Levy, R. C., Kleidman, R. G., Eck, T. F., Vermote, E., and Holben, B. N.: The MODIS aerosol algorithm, products, and validation., J. Atmos. Sci., 62, 947-973, doi:10.1175/JAS3385.1, 2005.

Roeckner, E., Brokopf, R., Esch, M., Giorgetta, M., Hagemann, S., Kornblueh, L., Manzini, E., Schlese, U., and Schulzweida, U.: Sensitivity of simulated climate to horizontal and vertical resolution in the ECHAM5 atmosphere model, J. Climate, 19, 37713791, 2006.

Sander, R., Kerkweg, A., Jöckel, P., and Lelieveld, J.: Technical note: The new comprehensive atmospheric chemistry module MECCA, Atmos. Chem. Phys., 5, 445-450, doi:10.5194/acp-5445-2005, 2005.

Sander, R., Baumgaertner, A., Gromov, S., Harder, H., Jöckel, P., Kerkweg, A., Kubistin, D., Regelin, E., Riede, H., Sandu, A., Taraborrelli, D., Tost, H., and Xie, Z.-Q.: The atmospheric chemistry box model CAABA/MECCA-3.0, Geosci. Model Dev., 4, 373-380, doi:10.5194/gmd-4-373-2011, 2011. 
Sayer, A., Hsu, N., Bettenhausen, C., Ahmad, Z., Holben, B., Smirnov, A., Thomas, G., and Zhang, J.: SeaWiFS Ocean Aerosol Retrieval (SOAR): algorithm, validation, and comparison with other data sets, J. Geophys. Res.-Atmos., 117, D03206, doi:10.1029/2011JD016599, 2012a.

Sayer, A. M., Hsu, N. C., Bettenhausen, C., Jeong, M.-J., Holben, B. N., and Zhang, J.: Global and regional evaluation of overland spectral aerosol optical depth retrievals from SeaWiFS, Atmos. Meas. Tech., 5, 1761-1778, doi:10.5194/amt-5-1761-2012, 2012b.

Sayer, A. M., Hsu, N. C., Bettenhausen, C. and Jeong, M.-J.: Validation and uncertainty estimates for MODIS Collection 6 "Deep Blue" aerosol data , J. Geophys. Res. Atmos., 118, 7864-7872, doi:10.1002/jgrd.50600, 2013.

Shehadeh, N. and Ananbeh, S.: The impact of climate change upon winter rainfall, Am. J. Environ. Sci., 9, 73-81, 2013.

Stokes, R. H. and Robinson, R. A.: Interactions in aqueous nonelectrolyte solutions, I. solute-solvent equilibria, J. Phys. Chem., 70, 2126-2131, doi:10.1021/j100879a010, 1966.

Tanré, D., Kaufman, Y. J., Herman, M., and Mattoo, S.: Multiangle Imaging Spectroradiometer (MISR) global aerosol optical depth validation based on 2 years of coincident Aerosol Robotic Network (AERONET) observations, J. Geophys. Res., 102, 1697116988, doi:10.1029/96JD03437, 1997.

Tiao, G., Reinsel, G., Xu, D., Pedrick, J., Zhu, X., Miller, A., DeLuisi, J., Mateer, C., and Wuebbles, D.: Effects of autocorrelation and temporal sampling schemes on estimates of trend and spatial correlation, J. Geophys. Res.-Atmos., 95, 20507-20517, 1990.

Tost, H., Jöckel, P., Kerkweg, A., Pozzer, A., Sander, R., and Lelieveld, J.: Global cloud and precipitation chemistry and wet deposition: tropospheric model simulations with ECHAM5/MESSy1, Atmos. Chem. Phys., 7, 2733-2757, doi:10.5194/acp-7-2733-2007, 2007.

van der Werf, G. R., Randerson, J. T., Giglio, L., Collatz, G. J., Mu, M., Kasibhatla, P. S., Morton, D. C., DeFries, R. S., Jin, Y., and van Leeuwen, T. T.: Global fire emissions and the contribution of deforestation, savanna, forest, agricultural, and peat fires (19972009), Atmos. Chem. Phys., 10, 11707-11735, doi:10.5194/acp10-11707-2010, 2010.

van Vuuren, D. P., Den Elzen, M. G., Lucas, P. L., Eickhout, B., Strengers, B. J., van Ruijven, B., Wonink, S., and van Houdt, R.: Stabilizing greenhouse gas concentrations at low levels: an assessment of reduction strategies and costs, Climatic Change, 81, 119-159, 2007.

van Vuuren, D., Edmonds, J., Kainuma, M., Riahi, K., Thomson, A., Hibbard, K., Hurtt, G., Kram, T., Krey, V., Lamarque, J.F., Masui, T., Meinshausen, M., Nakicenovic, N., Smith, S., and Rose, S.: The representative concentration pathways: an overview, Climatic Change, 109, 5-31, doi:10.1007/s10584-0110148-z, 2011a. van Vuuren, D., Edmonds, J., Kainuma, M., Riahi, K., and Weyant, J.: A special issue on the RCPs, Climatic Change, 109, 1-4, doi:10.1007/s10584-011-0157-y, 2011b.

Vestreng, V., Myhre, G., Fagerli, H., Reis, S., and Tarrasón, L.: Twenty-five years of continuous sulphur dioxide emission reduction in Europe, Atmos. Chem. Phys., 7, 3663-3681, doi:10.5194/acp-7-3663-2007, 2007.

Vestreng, V., Ntziachristos, L., Semb, A., Reis, S., Isaksen, I. S. A., and Tarrasón, L.: Evolution of $\mathrm{NO}_{x}$ emissions in Europe with focus on road transport control measures, Atmos. Chem. Phys., 9, 1503-1520, doi:10.5194/acp-9-1503-2009, 2009.

Weatherhead, E. C., Reinsel, G. C., Tiao, G. C., Meng, X.-L., Choi, D., Cheang, W.-K., Keller, T., DeLuisi, J., Wuebbles, D. J., Kerr, J. B., Miller, A. J., Oltmans, S. J., and Frederick, J. E.: Factors affecting the detection of trends: statistical considerations and applications to environmental data, J. Geophys. Res.-Atmos., 103, 17149-17161, 1998.

Weatherhead, E. C., Stevermer, A. J., and Schwartz, B. E.: Detecting environmental changes and trends, Phys. Chem. Earth, 27, 399403, 2002.

Wild, M.: Introduction to special section on global dimming and brightening, J. Geophys. Res.-Atmos., 115, D00D00, doi:10.1029/2009JD012841, 2010.

Wild, M., Gilgen, H., Roesch, A., Ohmura, A., Long, C. N., Dutton, E. G., Forgan, B., Kallis, A., Russak, V., and Tsvetkov, A.: From dimming to brightening: decadal changes in solar radiation at Earth's surface, Science, 308, 847-850, 2005.

Yoon, J. and Pozzer, A.: Model-simulated trend of surface carbon monoxide for the 2001-2010 decade, Atmos. Chem. Phys., 14, 10465-10482, doi:10.5194/acp-14-10465-2014, 2014.

Yoon, J., von Hoyningen-Huene, W., Kokhanovsky, A. A., Vountas, M., and Burrows, J. P.: Trend analysis of aerosol optical thickness and Ångström exponent derived from the global AERONET spectral observations, Atmos. Meas. Tech., 5, 12711299, doi:10.5194/amt-5-1271-2012, 2012.

Yoon, J., Burrows, J. P., Vountas, M., von Hoyningen-Huene, W., Chang, D. Y., Richter, A., and Hilboll, A.: Changes in atmospheric aerosol loading retrieved from space-based measurements during the past decade, Atmos. Chem. Phys., 14, 68816902, doi:10.5194/acp-14-6881-2014, 2014.

Zhang, J. and Reid, J. S.: A decadal regional and global trend analysis of the aerosol optical depth using a data-assimilation grade over-water MODIS and Level 2 MISR aerosol products, Atmos. Chem. Phys., 10, 10949-10963, doi:10.5194/acp-1010949-2010, 2010.

Zhang, Q., Streets, D. G., Carmichael, G. R., He, K. B., Huo, H., Kannari, A., Klimont, Z., Park, I. S., Reddy, S., Fu, J. S., Chen, D., Duan, L., Lei, Y., Wang, L. T., and Yao, Z. L.: Asian emissions in 2006 for the NASA INTEX-B mission, Atmos. Chem. Phys., 9, 5131-5153, doi:10.5194/acp-9-5131-2009, 2009. 